\title{
Oviposition preference and biological performance of Ceratitis capitata in Anacardiaceae, Cactaceae and Vitaceae fruit
}

\author{
Preferência de oviposição e performance biológica de Ceratitis capitata \\ em frutos de Anacardiaceae, Cactaceae e Vitaceae
}

\author{
Suzany Aguiar Leite ${ }^{1}$ (D), Daniela Ribeiro da Costa' ${ }^{1}$, Ana Elizabete Lopes Ribeiro ${ }^{2}$, \\ Aldenise Alves Moreira' (D), Raymundo José de Sá Neto' ${ }^{1}$, Maria Aparecida Castellani ${ }^{*}$
}

\begin{abstract}
The objective of this study was to compare the use of fruits of great economic and social importance for the northeast of Brazil by Ceratitis capitata Wied. (Diptera: Tephritidae) for oviposition, larval development, size and longevity of adults. Fruits of mango (Mangifera indica L.), quiabento (Pereskia bahiensis Gürke), forage palm [Opuntia ficus indica (L.) Mill] and grape (Vitis vinifera L.) were used, as well as flies from a hybrid laboratory population. Initially, four treatments (fruits) and six replications were used; the fruits were offered to 10 C. capitata couples, with later (96 hours) egg count. The second was conducted with six treatments and 10 replicates, offering two types of fruits simultaneously, combined two to two, to 10 C. capitata couples. The last bioassay comprised four treatments and six replicates, where $20 \mathrm{~g}$ of fruit were offered to 20 first-instar C. capitata larvae. After six days, the larvae were placed in plastic pots containing vermiculite until pupation, quantifying larval and pupal periods, viability and pupal mass, besides longevity and adult size. The data were submitted to ANOVA using the R Core Team software. Ceratitis capitata oviposits and completes its biological cycle in the four hosts studied, exhibiting no preference for oviposition and low biological performance in quiabento fruits. It yielded smaller adults and lower grape survival. Cactaceae palm and quiabento allow the survival of $C$. capitata in the laboratory, and this knowledge has been reported for the first time, proving that they can act as alternative hosts in the field.
\end{abstract}

KEYWORDS: Ceratitis capitata; Mangifera indica; Opuntia ficus indica; Pereskia bahienses; Vitis vinifera.
RESUMO: O objetivo do estudo foi comparar a utilizaçâo de frutos de importância econômica e social para o nordeste do Brasil por Ceratitis capitata Wied. (Diptera: Tephritidae) para oviposiçáo, desenvolvimento larval, tamanho e longevidade de adultos. Foram utilizados frutos de manga (Mangifera indica L.), quiabento (Pereskia bahiensis Gürke), palma-forrageira [Opuntia ficus indica (L.) Mill] e uva (Vitis vinifera L.) e moscas procedentes de uma população híbrida de laboratório. Inicialmente, utilizaram-se quatro tratamentos (frutos) e seis repetiçóes, com o oferecimento dos frutos a 10 casais de C. capitata, com posterior (96 horas) contagem de ovos. O segundo teste foi conduzido com seis tratamentos e 10 repetiçóes, oferecendo-se dois tipos de frutos simultaneamente, combinados dois a dois, a 10 casais de C. capitata. O último bioensaio compreendeu quatro tratamentos e seis repetiçóes, sendo oferecidos $20 \mathrm{~g}$ de fruto a 20 larvas de primeiro instar de C. capitata. Após seis dias, as larvas foram colocadas em potes plásticos contendo vermiculita até a empupação, quantificando-se: períodos larval e pupal, viabilidade e massa pupal e longevidade e tamanho do adulto. Os dados foram submetidos à análise de variância (ANOVA) pelo Programa R Core Team. Ceratitis capitata oviposita e completa seu ciclo biológico nos quatro hospedeiros estudados, exibindo náo preferência para oviposição e baixa performance biológica em frutos de quiabento. Este proporcionou adultos menores e a uva permitiu a menor sobrevivência. As cactáceas palma e quiabento permitem a sobrevivência de $C$. capitata em laboratório, sendo esse conhecimento relatado pela primeira vez, comprovando que essas espécies podem atuar como hospedeiros alternativos no campo.

PALAVRAS-CHAVE: Ceratitis capitata; Mangifera indica; Opuntia ficus indica; Pereskia bahienses; Vitis vinifera.

\footnotetext{
'Universidade Estadual do Sudoeste da Bahia - Vitória da Conquista (BA), Brazil. Universidade Federal do Oeste da Bahia - Barra (BA), Brazil. 


\section{INTRODUCTION}

The bioecology of fruit flies is influenced by several biotic and abiotic factors. Host availability and population density are important biotic factors influencing population dynamics, oviposition preference and biology of Ceratitis capitata (Wiedemman, 1824) (MONTES et al., 2011). The population fluctuation rises, when there is ease of feeding and oviposition, favoring larger infestations.

The relationship between population increase of fruit flies and the presence of host fruit is reported by several authors (ZUCCHI; MORAES, 2012). Polyphagous species exhibit behavioral flexibility, favoring their maintenance in the host circle, and selection of the oviposition substrate is considered a critical stage in the life cycle of frugivore Tephritidae.

Ceratitis capitata is the main species of fruit flies of quarantine importance and there is a need for strict population control of this pest when exporting to the United States and Japan. The introduction of C. capitata in new regions of Brazil is frequent, and it is widely distributed, with its presence recently registered in the states of Pará, Acre and Roraima, and no records of its occurrence only for the states of Sergipe, Amazonas and Amapá (ZUCCHI; MORAES, 2012).

The invasion of $C$. capitata is recent and has been occurring gradually due to its adaptability, with a tendency to occupy more and more niches in the region. The infestation occurred initially through exotic fruit introduced. This adaptation has been observed in several Brazilian regions, contributing to increase the number of host plant species of this fly; infestation has been verified in 96 species (ZUCCHI; MORAES, 2012).

The northeast region stands out as the most important producer of tropical fruit in the country, and São Francisco Valley is the main fruit growing pole, with emphasis on mango and grape cultivation. The majority of Brazilian grape and mango exports comes from the Sáo Francisco Valley (ARAÚJO; SILVA, 2013). Other fruit-growing poles of Bahia, such as Livramento de Nossa Senhora and the Rio Gavião Region, located in the southwest of the state, also aggregate mango, grape, passion fruit and banana crops, mainly (LEITE et al., 2016).

All aspects that may contribute to the increase in C. capitata population levels in the fruit poles deserve attention, including the presence of hosts near orchards. Some plant species not cultivated in large areas, and widely disseminated in the semi-arid fruit surroundings, are of great economic, social and cultural importance for rural communities and collaborate to maintain C. capitata in the production areas. Common hosts, such as forage palm [Opuntia ficus indica (L.) Mill] and quiabento (Pereskia bahiensis Gürke), used for animal feeding and live fences, respectively, have recently been associated with fruit flies. LEITE et al. (2017) reported for the first time the occurrence of $C$. capitata in forage palm and quiabento fruit, and of Anastrepha obliqua Mcquart in palm, in the Fruit pole of Livramento de Nossa Senhora, BA, and there is a need for confirmation on the possibility of acting as alternative hosts, when in the absence of primary hosts.

The objective of this study was to compare the use of fruit of great economic importance for Brazilian fruit harvesting, such as mango and grape, and of plant species of economic and social importance for the Brazilian northeast, such as the Cactaceae quiabento and forage palm, by C. capitata for oviposition, as well as their performance in the larval development, size and adult longevity.

\section{MATERIAL AND METHODS}

The studies were conducted from March to July 2015 at the Fruit Flies Laboratory of the State University of Southwest Bahia, UESB, Vitória da Conquista campus, Bahia state. The fruit used in the experiments were collected at Fruticulture de Livramento de Nossa Senhora, Bahia, and C. capitata flies were from a hybrid population kept at the Fruit Flies Laboratory of the State University of Southwest Bahia for 10 years.

\section{Acceptance and oviposition preference of Ceratitis capitata in exotic and native fruit}

In order to evaluate the acceptance of fruit oviposition by flies, a completely randomized design with four treatments and 10 replicates was conducted. The treatments consisted in offering 'Palmer' mango (Mangifera indica L.), 'Itália' grape (Vitis vinifera L.), forage palm (Opuntia ficus indica (L.) Mill) and quiabento (Pereskia bahienses Gürke) to C. capitata adults, according to the adapted methodology described by JOACHIM-BRAVO; SILVA-NETO (2004).

The fruit were partially covered with paraffin, leaving a surface of $2.25 \mathrm{~cm}^{2}$ without paraffin, positioned equidistantly, for exposure to females, aiming at oviposition. Two fruit of each plant species were placed in cages, containing cotton moistened with water and an artificial diet based on sugar and Biones. Subsequently, 10 C. capitata couples were released with 8 to 10 days of emergency. The cages were maintained at $25 \pm 2^{\circ} \mathrm{C}$. After a period of 96 hours, the fruit were removed, identified and frozen for later egg counting. 
The data were submitted to normality and homoscedasticity tests, transformed in $\log (\mathrm{x}+1)$ to meet the normality assumption, and submitted to the ANOVA test for a comparison of means by the Tukey test $(\mathrm{p}<0.05)$, using the $\mathrm{R}$ Core Team software, version 3.2.2 (R DEVELOPMENT CORE TEAM, 2015).

The oviposition preference was evaluated by another bioassay, using C. capitata couples of the same age (8 to 10 days). The methodology used was adapted from the studies of JOACHIM-BRAVO; ZUCOLOTO (1997a); JOACHIM-BRAVO; SILVA-NETO (2004); JOACHIMBRAVO et al. (2010).

The experimental design was completely randomized, with six treatments and 10 replicates. The treatments consisted in the concomitant offer of two types of fruit in the following combinations: mango $\mathrm{x}$ grape; mango $\mathrm{x}$ forage palm; mango $\mathrm{x}$ quiabento; grape $\mathrm{x}$ forage palm; grape $\mathrm{x}$ quiabento; forage palm $x$ quiabento. The flies were released in cages, which contained an artificial diet based on sugar and Biones ${ }^{\bullet}$ and cotton moistened in water. The evaluations consisted of counting the number of eggs after 96 hours, followed by the same procedures described for the acceptance bioassay for oviposition.

The data did not fit the ANOVA assumptions, and a Monte Carlo randomization was carried out, with a thousand simulations to guarantee $95 \%$ probability. To verify differences between the treatments, an orthogonal contrast was performed, a priori, using the R Core Team software, version 3.2.2 (R DEVELOPMENT CORE TEAM, 2015).

\section{Larval development, size and longevity of $\boldsymbol{C}$. capitata adults}

For the evaluation of larval development, a completely randomized design was conducted, with four treatments (palm, mango, grape and quiabento fruit) and six replicates. The fruit were offered in pieces of $20 \mathrm{~g}$ to 20 firstinstar C. capitata larvae. Fruit pieces were placed in Petri dishes lined with moist filter paper. They were replaced every two days and, after six days, the fruit pieces containing larvae were placed in plastic pots containing vermiculite until the pupal stage.

The evaluations were performed daily, and the following parameters were quantified: larval period; period, viability and pupal mass (puparium mass aged 24 hours); adult longevity and size, which is estimated by measuring the distance between the ribs $\mathrm{R} 4+5$ and cu-m of the right wing (ZUCOLOTO, 1987). To determine longevity, newly emerged flies from each treatment were sexed and same-sex individuals were packaged in a cage containing moistened cotton and an artificial diet based on sugar and Biones ${ }^{\bullet}$, with daily observations until the death of flies.
The data obtained were submitted to normality and homoscedasticity tests as well as to to the ANOVA test for comparison of means by the Tukey test $(\mathrm{p}<0.05)$, using the $\mathrm{R}$ Core Team software, version 3.2.2 (R DEVELOPMENT CORE TEAM, 2015).

\section{RESULTS AND DISCUSSION}

\section{Acceptance and oviposition preference of Ceratitis capitata in exotic and native fruit}

There were significant differences in the number of eggs found in the different fruit, from which the palm was highlighted with the highest mean number of eggs per exposure surface, differing from mango and quiabento (Fig. 1). The substrate acceptance hierarchy for oviposition was: palm $=$ grape $=$ mango $>$ quiabento, indicating that there is an oviposition preference; quiabento was the least suitable host.

The preference hierarchy for oviposition by C. capitata has been observed among fruit of different plant species (JOACHIM-BRAVO et al., 2001; JOACHIM-BRAVO; SILVA-NETO, 2004; COSTA et al., 2011), as well as intraspecific, such as grape cultivars (GÓMEZ et al., 2008), corroborating the results obtained in this study.

The oviposition rates in mango were low, a fact also reported by RATTANAPUN et al. (2009), for the species Bactrocera dorsalis, for 'Namdorkmai' and 'Oakrong' mango. Other studies report the preference for egg deposition by C. capitata (JOACHIM-BRAVO et al., 2001; JOACHIM-BRAVO; SILVA-NETO, 2004; JOACHIMBRAVO et al., 2010).

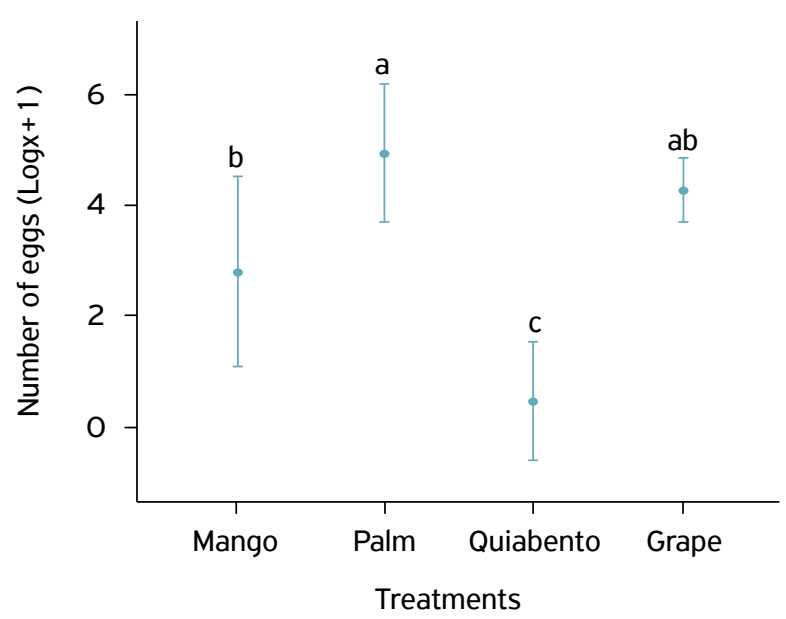

Figure 1. Mean number of eggs $C$. capitata in fruit of mango, palm, quiabento and grape. Means followed by equal letters do not differ by Tukey test $(p<0.05)$. Vitória da Conquista, BA, 2015. 
For oviposition preference, no significant difference was observed among the treatments, but it was verified that there was a preference among fruit of the same treatment, depending on the combination used. In the combinations of mango $x$ grape and mango $x$ palm, there was no oviposition in mango. In the mango and quiabento combination, the mean values of the two hosts were similar and slightly higher in mango, compared to quiabento. The oviposition in grape was higher, when combined with quiabento; palm oviposition was greater in the palm and mango combination. The number of eggs was higher when the host was combined with palm (Fig. 2).

Oviposition preference may be related to the protein requirements of the flies. Carbohydrates and acids provide energy and stimulate oviposition in C. capitata (JOACHIMBRAVO; AMORIM, 2006), as well as the nutritional value of the host, in general, also stimulate such behavior (JOACHIM-BRAVO; ZUCOLOTO, 1997b). FONTELLASBRANDALHA; ZUCOLOTO (2004) observed this relationship in A. obliqua, which prefers ovipositing on a substrate containing beer yeast and sucrose in relation to the substrate only with yeast.

Some data on the chemical composition of the fruit used in this research were found in the literature, except for quiabento fruit of the P. bahiensis species. Fruit of palm, grape and mango presented carbohydrate contents of $10.5 \%$ (CEREZAL; DUARTE, 2005), 29.2\% (SOUSA et al., 2014) and 16.5\% (MARQUES et al., 2010), respectively, whereas in $P$. aculeata leaves, it is $0.46 \%$ (SILVEIRA, 2015). In relation to protein, grape stands out with a higher

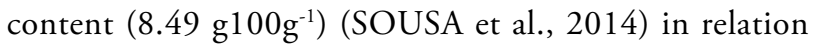

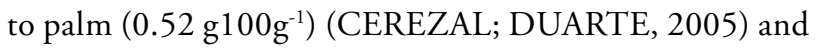

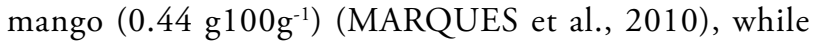
$P$. aculeata leaves had $23.3 \%$ protein. It is possible that the carbohydrate and protein contents of the fruit were

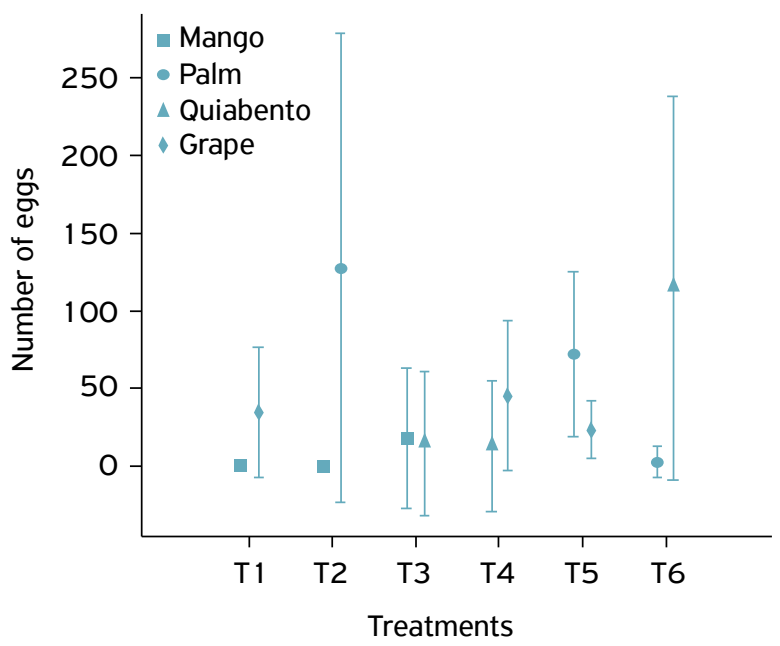

Figure 2. Mean number of eggs $C$. capitata in fruit of mango, palm, quiabento and grape. Vitória da Conquista, BA, 2015. used as criteria for the selection of the host for oviposition by $C$. capitata and that influenced the biological performance. However, it is not possible to raise hypotheses based only on the literature data. The ideal would be the accomplishment of chemical-physical analyses of the fruit used in the experiment for better results and its relations with the theories of host selection.

The results obtained for oviposition in palm and quiabento confirm the use of these plant species by C. capitata. The presence of fruit flies in these hosts was described by LEITE et al. (2017). MARSARO JÚNIOR et al. (2011) and GARCIA; NORRBOM (2011) also observed the oviposition of C. capitata in quiabento, but for the species Pereskia aculeata Mill.

\section{Larval development, size and longevity of $C$. capitata adults in exotic and native fruit}

The larval stage, quantified from first-instar larvae, presented smaller duration in mango, differing significantly from grape, whereas for palm and quiabento the larval times did not differ significantly for mango and grape. Mango was the host that allowed the smallest development period of the larval stage (Fig. 3A).

Survival ranged from $6.67 \%$ (quiabento) to $82.50 \%$ (mango). In grape, the mean survival was $64.17 \%$. The values were relatively low for palm $(45.83 \%)$ and quiabento (6.67\%) (Fig. 4).

For pupal mass, mango, palm and grape treatments differed significantly from that of Fig. 3B, showing that larvae fed on quiabento reach the pupal stage, but with lower pupal mass. Pupal period varied among the evaluated hosts (Fig. 3C).

For the total first-instar larval period to pupae, there was no significant difference among treatments (Fig. 3D). Grape was the host that presented the largest larval and pupal period, demonstrating that it was not a very adequate host. It was observed that mango and palm presented a statistically equal total period, differing only from grapes. Quiabento provided a total intermediate development period.

The results of pupal viability demonstrated that there was no significant difference among treatments (Fig. 3E). Palma was the host with the lowest emergence percentage.

Adults that emerged from mango, palm and grape fruit presented similar wing size, with no significant differences between them (Fig. 3F). However, the adult from quiabento fruit showed a significantly smaller wing size when compared to the others, which is an indication that this fruit is not a suitable host for C. capitata, but allows the pest to complete its cycle. In other studies with C. capitata and papaya and apple fruit (JOACHIM-BRAVO; ZUCOLOTO, 1997a); 
papaya and orange (JOACHIM-BRAVO et al., 2010) and acerola, cashew, star fruit, guava, graviola (COSTA et al., 2011), no differences were observed in the wing size of C. capitata adults.

The survival of $C$. capitata adults presented a similar longevity pattern for hosts, and mango was the host that yielded the longest-lived adults (Fig. 5). Mean adult longevity was relatively low, ranging from 16.92 to 19.67 days.
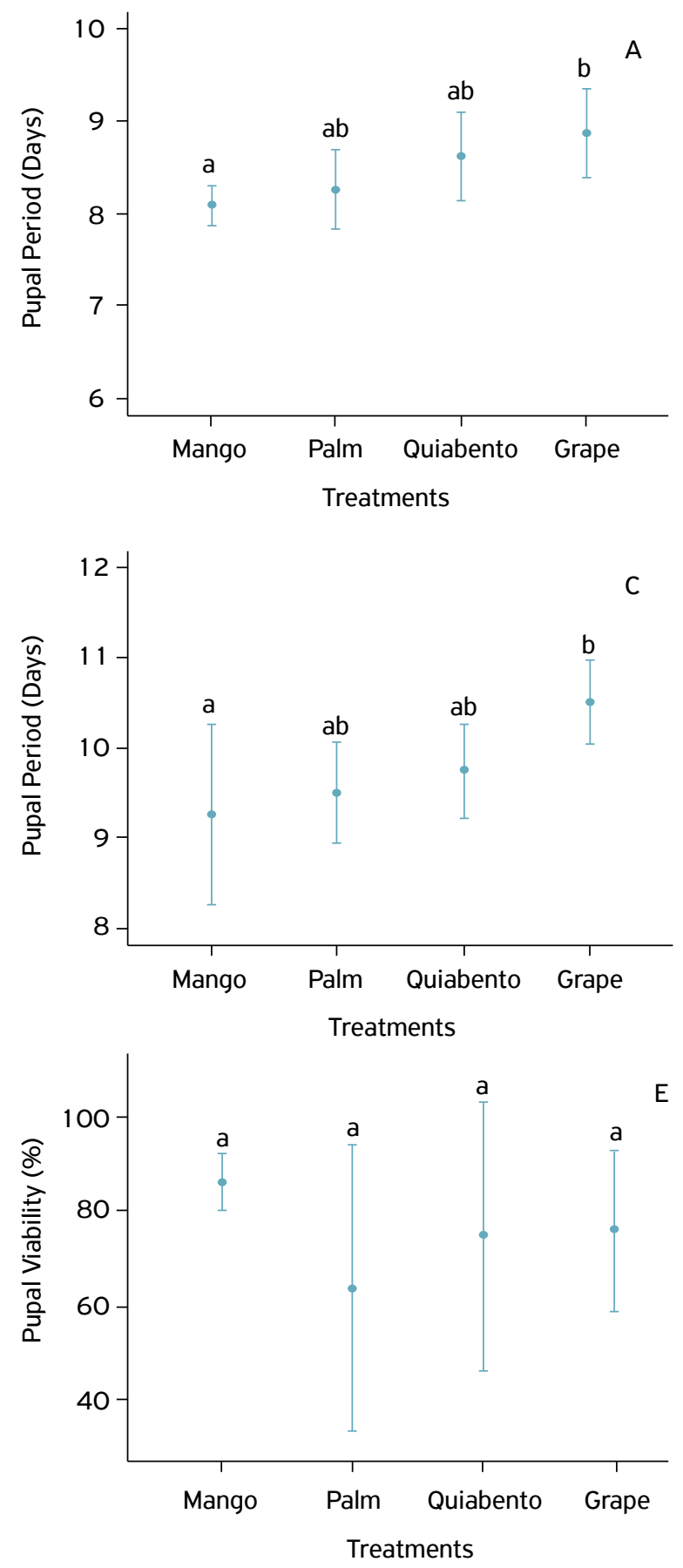

ZANARDI et al. (2011) observed a shorter larval development period of C. capitata in peach; for JOACHIMBRAVO et al. (2001), apple was an inadequate host to the development of the insect due to the low emergence percentage.

Palm survival (45.83\%) was similar to that observed in 'Golden Delicious' apple (40.0\%) by PAPADOPOULOS et al. (2002). In general, the values obtained were lower
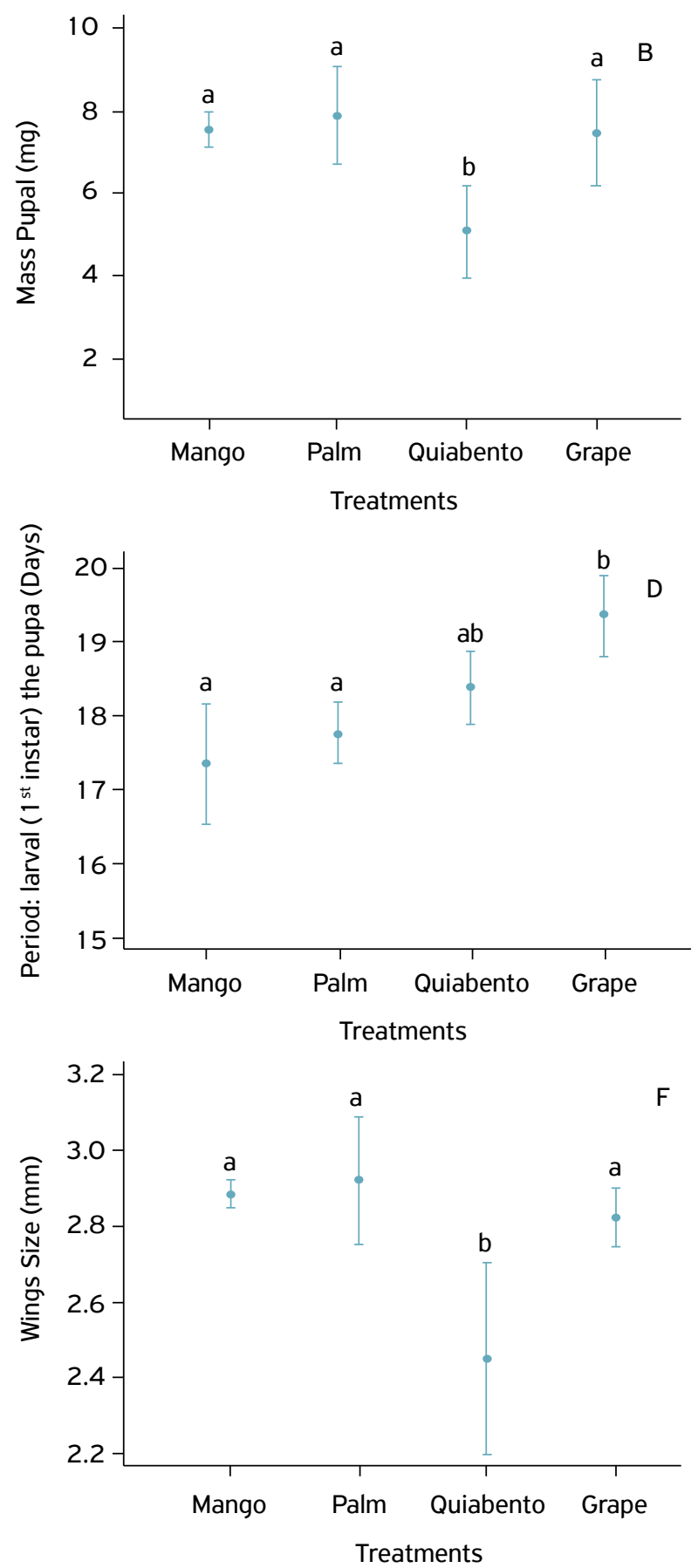

Figure 3. Larval period of $1^{\text {st }}$ instar C. capitata (A), Mass pupal (B), Pupal Period (C), Period total of development (D), Pupal viability (E) e Wing size (F) of $C$. capitata created in four types of fruit. Means followed by equal letters do not differ by Tukey test $(p<0.05)$. Vitória da Conquista, BA, 2015. 
than those observed by ZANARDI et al. (2011) in grapes. The results are similar to studies conducted with $C$. capitata by PAPADOPOULOS et al. (2002) in 'Golden Delicious' apple and by ZANARDI et al. (2011) in peach, apple, persimmon and grape fruit.

JOACHIM-BRAVO; ZUCOLOTO (1997a) obtained an emergence percentage of 15 and $86.70 \%$ in apple and papaya, respectively. In papaya and orange, the percentages were 70.0 and $68.3 \%$, respectively (JOACHIMBRAVO et al., 2010). For acerola, star fruit, guava, graviola and cashew, emergence was $28.7 ; 60.7 ; 76.6 ; 87.3$ and $45.3 \%$, respectively (COSTA et al., 2011). In 'Golden Delicious' apple, the survival rate was higher than 40 days (PAPADOPOULOS et al., 2002). In orange, the survival rate was 34.8 days (JOACHIM-BRAVO et al., 2010). Guava, cashew, star fruit and graviola yielded longevity similar to C. capitata adults (COSTA et al., 2011). ZANARDI et al. (2011) observed that flies from peach fruit survive up to

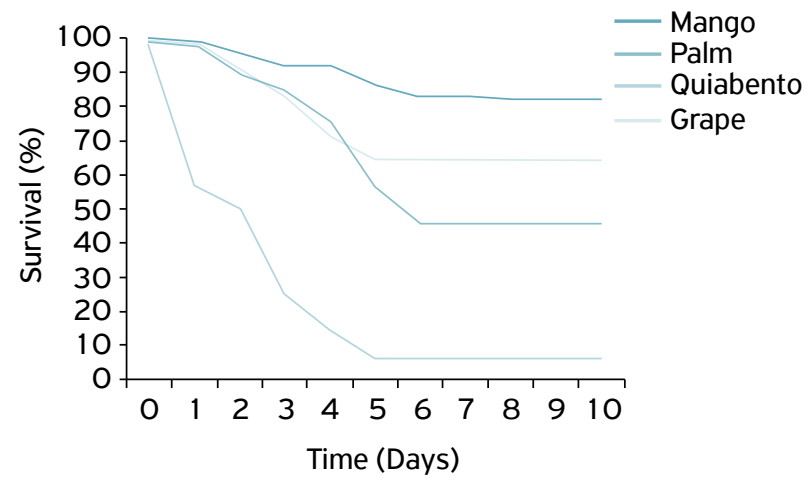

Figure 4. Percentage of survival of larvae $C$. capitata created in fruit of mango, palm, quiabento and grape. Vitória da Conquista, BA, 2015.

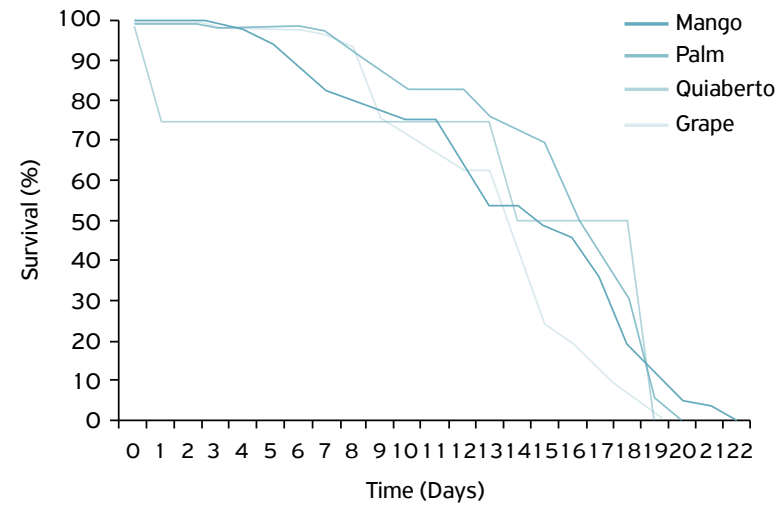

Figure 5. Survival of adults $C$. capitata from larvae created in fruit of mango, palm, quiabento and grape. Vitória da Conquista, BA, 2015.
79 days, and this is the best host of the four studied for the development of C. capitata.

Based on the results of the biological parameters studied for C. capitata in the laboratory, it can be inferred that exotic hosts (palm, mango and grape) yielded a better development of $C$. capitata, when compared to the native quiabento fruit. The study reveals that the four hosts are fruit fly multipliers; therefore, control measures should be adopted, since, in the absence of a preferred host, C. capitata can use other hosts as a way of maintaining the species.

Of the four hosts studied, two are of great commercial value, such as mango and grape, whereas palm and quiabento are two cacti commonly present in the semiarid. Palm has in its rackets an animal feed source during the dry period, and quiabento is commonly used as a hedge on most properties. Both cactaceae have been shown to be maintenance hosts for the C. capitata species in the semiarid region of Bahia (LEITE et al., 2017) and probably in the Northeast of Brazil, and it is important to consider forage palm and quiabento in integrated management programs of fruit flies.

The data obtained show the adaptive capacity of C. capitata to other hosts, allowing to verify that, in the absence of a primary host, the species searches for another source to be used as a maintenance host. These records lead to changes in the monitoring systems in the semi-arid areas of Bahia and Northeast, as in the vicinity of most of the properties there are forage palm plantations, as well as the use of quiabento as a hedge.

\section{CONCLUSIONS}

Ceratitis capitata oviposits in palm (Opuntia ficus-indica) and quiabento (Pereskia bahiensis) fruit in the laboratory.

Ceratitis capitata completes the biological cycle in mango (Mangifera indica), palm (Opuntia ficus-indica), quiabento (Pereskia bahiensis) and grape (Vitis vinifera) fruit; quiabento is the least suitable host.

The cactaceae palm (Opuntia ficus-indica) and quiabento (Pereskia bahiensis) allow the survival of Ceratitis capitata, and this knowledge has been reported for the first time.

\section{ACKNOWLEDGEMENTS}

This study was financed in part by the Coordenação de Aperfeiçoamento de Pessoal de Nível Superior - Brasil (CAPES) - Finance Code 001. The authors also thank the Postgraduate Program in Agronomy of UESB. 

REFERENCES

ARAÚJO, G.J.F.; SILVA, M.M. Crescimento econômico no semiárido brasileiro: $O$ caso do polo frutícola Petrolina/Juazeiro. Caminhos de Geografia, Uberlândia, v.14, n.46, p.246-264, 2013.

CEREZAL, P.; DUARTE, G. Some characteristics of cactus pear (Opuntia ficus-indica (L.) Miller) harvested in the andean altiplano of region 2 of Chile. Journal of the Professional Association for Cactus Development, Kingsville, v.7, p.34-60, 2005.

COSTA, A.M.; AMORIM, F.O.; ANJOS-DUARTE, C.S.; JOACHIMBRAVO, I.S. Influence of different tropical fruits on biological and behavioral aspects of the Mediterranean fruit fly Ceratitis capitata (Wiedemann) (Diptera.Tephritidae). Revista Brasileira de Entomologia, Curitiba, v.55, n.2, p.355-360, 2011 . http://dx.doi.org/10.1590/ S0085-56262011005000039

FONTELLAS-BRANDALHA, T.M.L.; ZUCOLOTO, F.S. Selection of Oviposition sites by wild Anastrepha obliqua (Macquart) (Diptera: Tephritidae) based on the nutritional composition. Neotropical Entomology, Londrina, v.33, n.5, p.557-562, 2004. http://dx.doi. org/10.1590/S1519-566X2004000500003

GARCIA, F.R.M.; NORRBOM, A.L. Tephritoid flies (Diptera, Tephritoidea) and their plant hosts from the state of Santa Catarina in southern Brazil. Florida Entomologist, Gainesville, v.94, n.2, p.151-157, 2011.

GÓMEZ, M.; PARANHOS, B.J.; DAMASCENO, I.; CASTRO, R.; CAMPO, D.; ANDRADE, K.; SILVA, M.; NASCIMENTO, A.S.; MALAVASI, A. Biología de la mosca del mediterrâneo, Ceratitis capitata Wiedemann (Diptera: Tephritidae) em dos variedades de uva de mesa (Vitis vinifera L.) en el nordeste brasileño. CitriFrut, Ciudad de la Habana, v.25, n.2, p.1823, 2008.

JOACHIM-BRAVO, I.S.; FERNANDES, O.A.; BORTOLI, S.A.; ZUCOLOTO, F.S. Oviposition behavior of Ceratitis capitata Wiedemann (Diptera: Tephritidae): Association between oviposition preference and larval performance in individual females. Neotropical Entomology, Londrina, n.30, v.4, p.559-564, 2001. http://dx.doi.org/10.1590/ S1519-566X2001000400008

JOACHIM-BRAVO, I.S.; ZUCOLOTO, F.S. Oviposition preference and larval performance in Ceratitis capitata (Diptera, Tephritidae). Revista Brasileira de Zoologia, Curitiba, n. 14, v.4, p.795-802, 1997a. http://dx.doi.org/10.1590/ S0101-81751997000400004

JOACHIM-BRAVO, I.S.; ZUCOLOTO, F.S. Oviposition preference in Ceratitis capitata (Diptera, Tephritidae): influence of rearing diet. Iheringia, Série Zoologia, Porto Alegre, v.82, n.4, p. 133-140. $1997 \mathrm{~b}$.

JOACHIM-BRAVO, I.S.; SILVA-NETO, A.M. da. Aceitação e preferência de frutos para oviposição em duas populações de Ceratitis capitata (Diptera, Tephritidae). Iheringia, Série Zoologia, Porto Alegre, v.94, n.2, p.171-176, 2004. http://dx.doi. org/10.1590/S0073-47212004000200009
JOACHIM-BRAVO, I.S.; AMORIM, F.O. Efeito de duas substâncias atrativas no comportamento alimentar, limiar de discriminação e longevidade de adultos de Ceratitis capitata (Wiedemann, 1824) (Diptera: Tephritidae). Sitientibus Série Ciências Biológicas, Feira de Santana, v.6, n.4, p.231-236, 2006.

JOACHIM-BRAVO, I.S.; GUIMARÃES, A.N.; MAGALHÃES, T.C.; NASCIMENTO, A.S. Performance de Ceratitis capitata Wiedemann (Diptera: Tephritidae) em frutos: comparação de duas populações criadas em laboratório. Neotropical Entomology, Londrina, v.39, n.1, p.9-14, 2010. http://dx.doi.org/10.1590/ S1519-566X2010000100002

LEITE, S.A.; CASTELLANI, M.A.; RIBEIRO, A.E.L.; MOREIRA, A.A.; AGUIAR, W.M.M. Perfil dos fruticultores e diagnóstico do uso de agrotóxicos no polo de fruticultura de Livramento de Nossa Senhora, Bahia. Extensão Rural, Santa Maria, v.23, n.2, p. $112-$ 125, 2016. http://dx.doi.org/10.5902/2318179613538

LEITE, S.A.; CASTELLANI, M.A.; RIBEIRO, A.E.L.; COSTA, D.R.; BITTENCOURT, M.A.L.; MOREIRA, A.A. Fruit flies and their parasitoids in the fruit growing region of Livramento de Nossa Senhora, Bahia, with records of unprecedented interactions. Revista Brasileira de Fruticultura, Jaboticabal, v.39, n.4, p. e-592, 2017. http://dx.doi.org/10.1590/0100-29452017592

MARQUES, A.; CHICAYBAM, G.; ARAUJO, M.T.; MANHÃES, L.R.T.; SABAA-SRUR, A.U.O. Composição centesimal e de minerais de casca e polpa de manga (Mangifera indica L.) CV. Tommy Atkins. Revista Brasileira de Fruticultura, Jaboticabal, v.32, n.4, p. 1206-1210, 2010. http://dx.doi.org/10.1590/ so100-29452010005000117

MARSARO JÚNIOR, A.L.; SOUZA-FILHO, M.F.; SILVA, R.A.; STRIKIS, P.C. First report of natural infestation of Pereskia aculeata Mill. (Cactacea) by Ceratitis capitata (Wiedemann) (Diptera: Tephritidae) in Brazil. Revista de Agricultura, Piracicaba, v.86, n.2, p. 152154, 2011.

MONTES, S.M.N.M.; RAGA, A.; SOUZA-FILHO, M.F.de. Dinâmica populacional de moscas-das-frutas e parasitoides em cultivares de pessegueiros (Prunus persica L. Batsch) no município de Presidente Prudente -SP. Revista Brasileira de Fruticultura, Jaboticabal, v.33, n.2, p.402-411, 2011.

PAPADOPOULOS, N.T.; KATSOYANNOS, B.I.; CAREY, J.R. Demographic parameters of the Mediterranean fruit fly (Diptera: Tephritidae) reared in apples. Annals of the Entomological Society of America, College Park, v.95, n.5, p.564-569, 2002.

RATTANAPUN, W.; AMORNSAK, W.; CLARKE, A.R. Bactrocera dorsalis preference for and performance on two mango varieties at three stages of ripeness. Entomologia Experimentalis et Applicata, Dordrecht, v.131, n.3, p. 243-253, 2009. https:// doi.org/10.1111/j.1570-7458.2009.00850.x

R DEVELOPMENT CORE TEAM. R: A language and environment for statistical computing. Vienna: R Foundation for Statistical Computing, 2015. Available from: <http://www.R-project.org/>. 
SILVEIRA, M.G. Ensaio nutricional de Pereskia spp.: Hortaliça não convencional. 2016. 174f. Thesis (Doutorado em Ciência dos Alimentos) - Universidade Federal de Lavras, Lavras, 2015.

SOUSA, E.C.; UCHÔA-THOMAZ, A.M.A.; CARIOCA, J.O.B.; MORAIS, S.M.; LIMA, A.; MARTINS, C.G.; ALEXANDRINO, C.D.; FERREIRA, P.A.T.; RODRIGUES, A.L.M.; RODRIGUES, S.P.; SILVA, J.N.; RODRIGUES, L.L. Chemical composition and bioactive compounds of grape pomace (Vitis vinifera L.), Benitaka variety, grown in the semiarid region of Northeast Brazil. Food Science and Technology, Campinas, v.34, n.1, p.135-142, 2014. http://dx.doi.org/10.1590/ SO101-20612014000100020
ZANARDI, O.Z:; NAVA, D.E; BOTTON, M.; GRÜTZMACHER, A.D.; JUNIOR MACHOTA, R.; BISOGNIN, M. Desenvolvimento e reprodução da moscado-mediterrâneo em caquizeiro, macieira, pessegueiro e videira. Pesquisa Agropecuária Brasileira, Brasília, v.46, n.7, p.682-688, 2011.http://dx.doi.org/10.1590/SO100-204X2011000700002

ZUCCHI, R.A.; MORAES, R.C.B. Fruit flies in Brazil - Hosts and parasitoids of the Mediterranean fruit fly. 2012. Available from: <www.lea.esalq.usp.br/ceratitis/>. Accessed on: Oct. 052018.

ZUCOLOTO, F.S. Feeding habits of Ceratitis capitata can larvae recognize nutritional effective diet? Journal Insect Physiology, Texas, v.33, n.5, p.349-353, 1987. 